\title{
高温曝露白ネズそに関する実験的研究
}

第 3 報 高溫曝露白ネズミの白血球像に及方す各種薬剂の影響

\section{Study on Rat Exposed to High Temperature}

III. Effects of some Drugs on Leucocytes Counts of Warmed Rat

\author{
鹿児島大学医学部会衆衞生学教室 (主任 西尾一男教授) \\ 鹿児島大学医学部衞生学教室 (主任 北原経太教授) \\ 宮 本 利 哉 \\ Toshiya Miyamoto \\ Department of Public Health, School of Medicine, Kagoshima University \\ (Director: Prof. Kazuo Nishio) \\ Department of Hygiene, School of Medicine. Kagoshima Universityt \\ (Director: Prof. Keida Kitahara)
}

前報 ${ }^{12)}$ で白ネズミが高温に曝露された場合の血液像, 血液カタラーゼ活性の変動および蔵器の $\mathrm{P}^{32}$ 配分と含水 量の変化を報告した。白ネズミ党気温 $40.0^{\circ} \mathrm{C}$ 高温に30 分間曝露すると血液像と血液カタラーゼ活性值には変動 が現われ，特に白血球数上白血球百分率仁定型的な变動 が現われる。すなわち白ネズミの白血球数と白血球百分 率について高温 $\left(40.0^{\circ} \mathrm{C}\right)$ 飞曝露（30分）方直前と， 曝露解放の直後，1.5時間目捛よび 3 時間目己に観察す ると, 第 1 図のよ5 の約 $1 / 5 \sim 1 / 2$ 減少し, $1.5 \sim 3$ 時䦎以㥀前值の約 $1 / 4$ 〜 倍増加し, 72時間目には大体㨁前值に戻る。一方, 白血球百分率は解放の直後には淋巴球が減少し, 好中球 は増多し，1.5〜 3 時間にはしの関係はさらに強くなり 24〜48時間で回復する。すなわち白ネズミの $40.0^{\circ} \mathrm{C}, 30$ 分曝露解放直後の白血球数の減少淰淋巴球の減少心より これに続く増加は好中球の増加によるものである。

空た $40.0^{\circ} \mathrm{C}, 30$ 分の高温曝露は第 2 報 ${ }^{2)}$ 亿報告したよ うに燐代謝にも影響する。すなわち $\mathrm{P}^{32}$ 㵴器配分は解放 の直後こは腎, 血液, 心で増加し, 3 時間目には肝臓で 増加する。とのような $\mathrm{P}^{32}$ 臟器配分の時間的変動から考 察する己 $40^{\circ} \mathrm{C}, 30$ 分の曝露解放直後には曝露中の生体の 変化が厓とんどそのま点残存し，3時閒目には曝露によ る変化からの回復が積極的儿招こなわ札ていると考光ら 往。

以上のような高温曝露の白血球百分率之燐代謝儿及济 す変化交併于考えると, 白血球数の曝露解放後の減少心 続いて起る増加は燐代謝回復過程と相忘する。ただしこ
の際特記すべをここは燐代謝追跡子こして皮下注射した

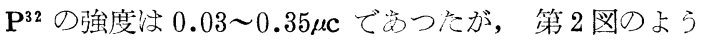

\section{第 1 図 高温曝露による白血球数， $\mathrm{E}$} 球数, 白血球像の変動
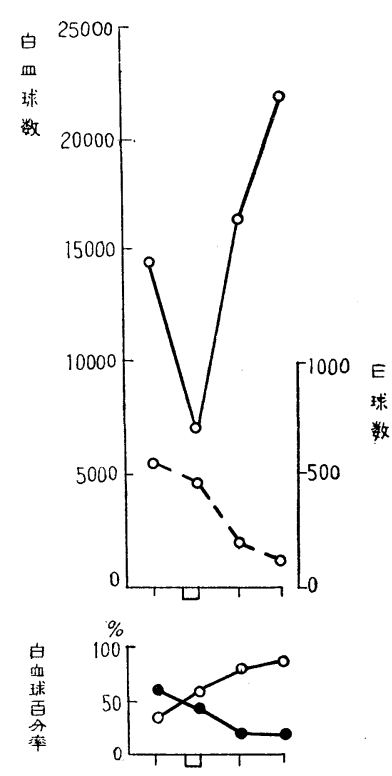

$40.0^{\circ} \mathrm{C} 30$ 分の高温曝露を意味する。

$\bigcirc$ 一 白血 球

O- - $\mathrm{E}$ 球

白血球百分率では

$\bigcirc$ - $\bigcirc$ 好中球

- E 球 
第 2 図 $\mathbf{P}^{32}$ 皮注後高温に曝露したときの白血 球, $\mathrm{E}$ 球数の変動

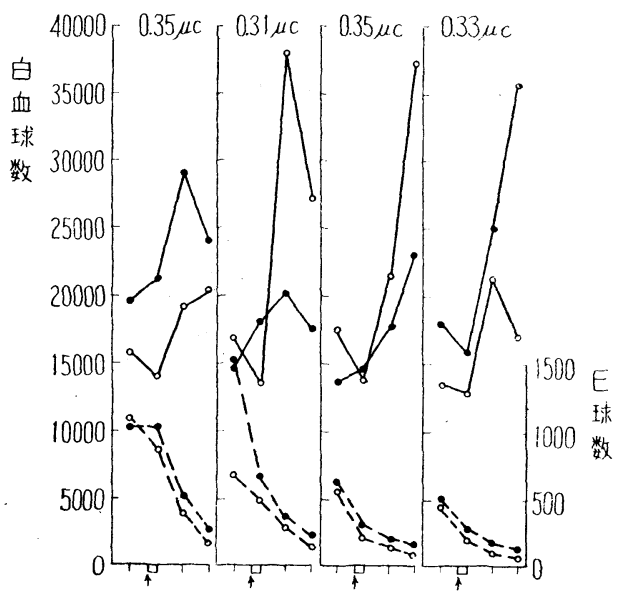

$\left.\begin{array}{ll}\uparrow & \mathrm{P}^{32} \text { 皮下注射 } \\ \square & 40.0^{\circ} \mathrm{C}, 30 \text { 分の高温曝露 }\end{array}\right\}$ を意味する。

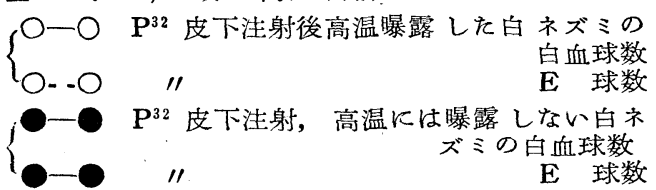

白血球数は 3,000 以上の变動を有意とした。

に上記の高塩曝露解放直後の定型的な白血球数の減少は みられなかつ核。そこで本実験では $\mathrm{P}^{32}$ 以外の白血球数 を変動させるような薬剂堂いくつか選び，とれらの薬剂 による前処置が上記の高温曝露後の白血球数異常の定型 性にでうひびくかを迫求し，高温曝露反応としての白血 球数変化の生物学的意義, ひいては高温環境化対吉各自 律神経系の反応について考察を一歩進めるとと意図し た。

\section{実験方法}

環境温走 $40.0^{\circ} \mathrm{C}$ 亿夺る高温箱, 白血球百分率, 白血球 数招よび循環好酸球数 (以下 $\mathrm{E}$ 球数々略記) の測定法, 測定の時間，薬凨の注射部位（筋注の場合は左後肢）掠 よび方法などはすべて第 1 報1比記しとと抢りで，薬剮 注射前 $1 \sim 1.5$ 時間の測定值正常值とした。実験に使 用した薬剂㳉 Whooping cough vaccine (熊本化血研 製), Adrenaline ( $0.1 \%$ 瑥化エピレナミン, 第 1 製薬), Chlorpromazine (ウインタミン, 塩野義), ACTH (Acthar, Armour Laboratories) Diiodtyrosine (Roche) 抗甲状腺ホルモン MER (Mercazole, 中外) の6 種である。当初高温環境汇生体が置かれた場合下垂体一
甲状腺系の密接な関連に留意して, Thyroxine (Roche) で動物を前処置するつもりであつたが，Thyroxineの 標品が古いものであつたので予備実験としてThyroxine 注射夜をペーパークロマトグラフにより $\mathrm{CH}_{3} \mathrm{COOH}-$ Butanol-水(78:28:2)で展開してみ炎。結果は Ninhydrin および Diazo 反応で Thyroxine Dijodtyrosine に分解していることを知つたので，甲状 腺の高温炆しているととを知つたのて，甲状腺の高温 に対する態度々上述の白血球数変動との観察に Dijodtyrosine として使用した。各薬剤について 2 例ずつ高温 曝露実験を打てなつた。実験使使用した白ネズミ法成 熟, 健康で体重 180 270 g, 早は未受胎のもの主用心 高温爆露例已対照例拄同一の性のものを使用した。

\section{実 験 成績}

これら 6 種の薬剂でそれぞれ前処置して高温汇曝露し たの5の白血球数増減の傾向は次の 4 つの型に要約さ视 る。

（1）白血球数化対する薬剤の作用と高温嚗露によ る作用が単に重り合う場合。

（2）曝露解放直後には単純高温曝露の場合上同様 に著明《減少するが，その後の増加は藷明でない場合。

(3) 懪露解放後の白血球数减少もこれに続く增加 も明瞭ではないが明らかにその傾向のある場合。

（4）懪露解放の直後も, それ以後も全然白血球数 飞変動のない場合。

このような薬凧の前処置によつて高温曝露時の定型的 白血球数変動, 寸なわ減少とそれに続く増加の像快く ずれてくる。その各々の場合について述べる。

\section{1) の場合}

Whooping cough vaccine または Adrenaline で前処 置する之白血球数は増加するが，その増加の極期に高温 に懪露すると単純懪露のとさと同じょうに白血球数は解 放後に以曝露直前値に対しては著明に減少しそれ続い て 1.5〜 3 時間目には増加する。すなわち高温曝露解放 後の白血球数の淋巴球减少に上る減少ととれに続く好中 球増加による増加は Adrenaline gh vaccine に上つて影響されない。

Joseph A. Tuta 汸幼弱家兔で Whooping cough vaccine 注射による白血球数増加を認めて抢り ${ }^{9)}$, 井上はこ 狄定追試確認している101が国産品では增加作用はなかつ たという。しかし筆者の予備実験では，熊本化血研製 vaccine 5 倍稀夜 $6.0 \mathrm{cc} / \mathrm{kg}$ 皮下注射後 $5 \sim 6$ 時間目に は確実に白血球数增加が現われた。Whooping cough 


\section{第 3 図 WHooping Cough Vaccine による実験}

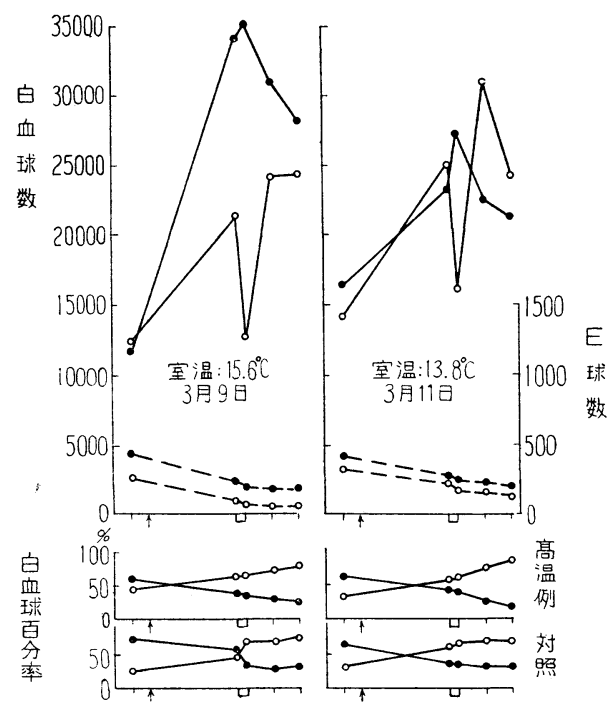

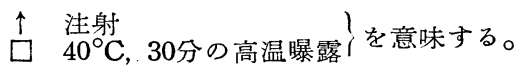

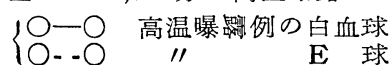
8-8 対照白血球

白血球百分率では

○一○ 好中球

○一淋巴球

vaccine による白血球数増加は第 3 図のように対照動物 では曝露動物の解放直後に当る時期, 寸なわち注射後 5 時間目以後増加から減少に移るが, 懪露動物の開放後 3 時間目飞当る時期（注射後 8.5 時間目）にもな招正常 值よりは増加している。高温曝露動物では $\mathrm{E}$ 球数は減少 乙, 白血球百分率注白血球数诚少時汇淋巴球百分率が 低下し，增加時には好中球百分率が増加するという単純

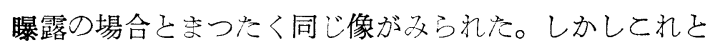

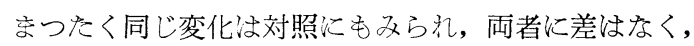
このととは他の薬剤前処置によるすべての場合にも起 た。しかし対照では注射により白血球数がまず減少し， ついで増加学すということは宗つたくなかた。

Adrenaline を注射すると白血球数が増加することは 古〈から知られている11-18) $0.1 \%$ 塩化エピレナミンの 10 倍稀液学 $5.0 \mathrm{cc} / \mathrm{kg}$ 皮下注射すると 2 時間目には確実 に白血球数が増加するのを確めた。とのような前処置後 2 時間目に高温に曝露すると, 白血球数は第 4 四のょう に解放直後には曝露直前値より著明減少し, その後の 増加も著しい。な扮 Adrenaline 皮注により体温の下降 が報告されているが20)，本実験では投与量が小さく測定
第 4 図 Adrenaline による実験
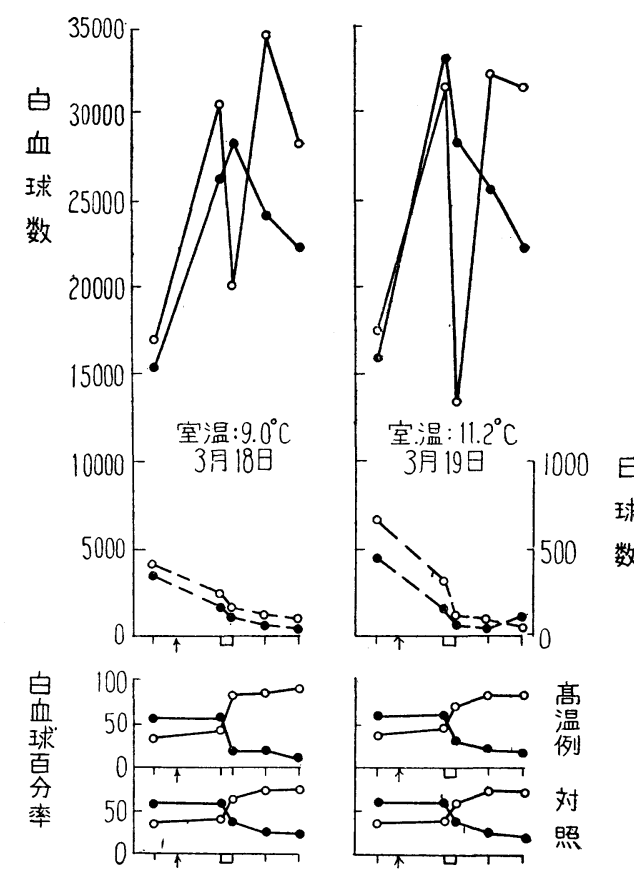

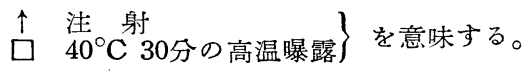
今O-O 高温曝露例の白血球

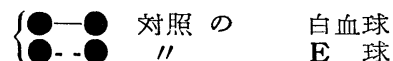

白血球百分率では

○一 $\bigcirc$ 好中球

-—淋巴球

期間内には体温の下降淰認められなかつた。

\section{2) の場合}

ACTH または Diiodtyrosine で前処置して高温に懪 露した場合がとれに属する。

ACTH による前処置の場合は Acthar (Amour Laboratories) $1.0 \mathrm{mg} / \mathrm{kg}$ 筋注し, Thorn test ${ }^{211}$ に準じて注 射後 4 時間目の時期に, 高温飞曝露した。第 5 図のよ 5 に高温曝露解放の直後には白血球数は定型的に減少し, ついで増加する傾向はあるが著明ではない。Diiodtyrosine の場合は $500 / \mathrm{kg}$ 皮注で前処置した。白血球数は 注射後 2 時間目には正常值とほとんど差がなく，2 時間 目に高温に懪露すると第 6 四のよ 5 に白血球数は解放の 直後には昵膫に減少するが, その後の増加が著明ではな い。しかし ACTH 前処置の場合よりは強い傾向があ る。 
第5図 ACTH による実験
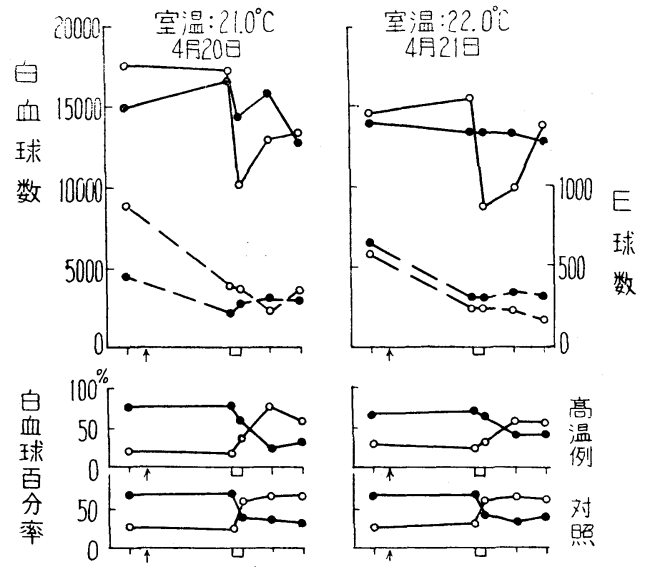

品 $\quad$ 注射 30 分高温曝露了を意味する。 1- 高温曝露例の白血球 10-. 11 E 球 \{-8 対照 $\quad$ 白血球 白血球百分率では

$\mathrm{O}$ - $\mathrm{O}$ 好中球

一 淋巴球

第6 図 Diiodtyrosine による実験
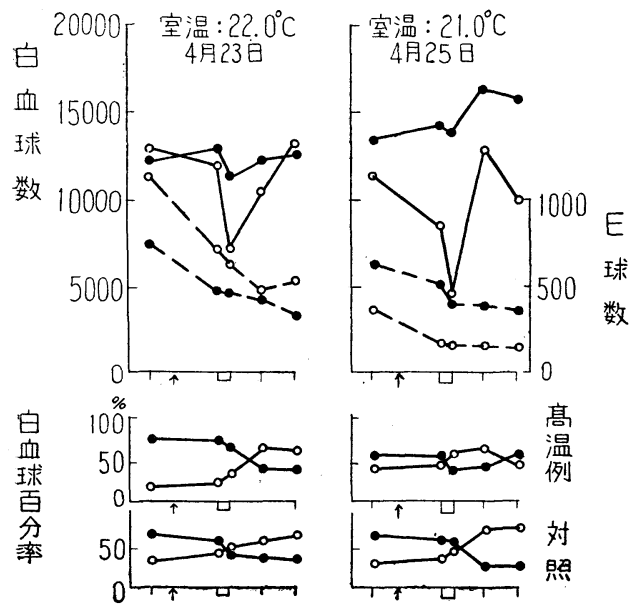

○ 注射 30 分高温瀑露〕を意味する。

$\left\{\begin{array}{l}\mathrm{O}-\mathrm{O} \text { 高温曝露例の白血球 } \\ \mathrm{O}-\mathrm{O} \text { 球 }\end{array}\right.$

\{8-8 対照の 白血球

白血球百分率では

$\mathrm{O}$ 一 $\mathrm{O}$ 好中球

一一淋巴球

\section{第 7 図 抗甲状腺ホルモン $($ MER $)$ による実験}
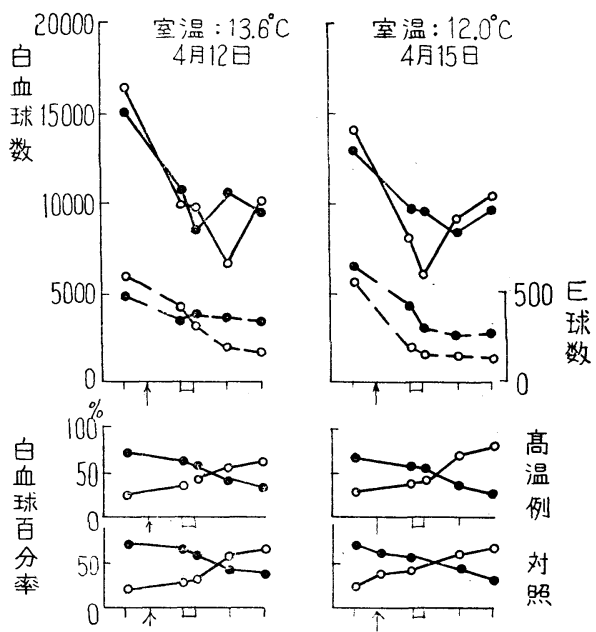

$\uparrow \quad$ 注射 30 分高温曝露\}を意味する。

10 - 0 高温曝露例の白血球

\{O-. 11 E 球

亿O-8 対照の $\quad$ 白血球

白血球百分率では

○一○ 好中球

-1. 淋巴球

\section{3）の場合}

抗甲状腺 ホルモン Mercazole で前処置, すなわち Mercazole $50 \mathrm{mg} / \mathrm{kg}$ 皮注後 1.5 時間目には確実伯血 球数は減少する。乙の時期に高温に曝露すると, 白血球 数は解放直後には曝露直前值に対しては減少し, ついで 増加する傾向はあるが, 第 7 図のようにこの減少も増加 む定型的とはいいがたい。

\section{4）の場合}

Chlorpromazine の有效量は研究者により, 宗た研究 目的に応じてまちまちである。Chlorpromazine (ウイ ンタミン） $20 \mathrm{mg} / \mathrm{kg}$ を皮下注射すると 2 時間目には第 8 図に示すように白血球数は確実汇減少する。この時期に 高温に曝露すると白血球数は第 8 図のようと解放の直後 もそれ以後もほとんご変動しない。Chlorpromazine で 前処置すると体温の低下が著明で, 第 9 図のよ 5 に注射 後 1.5 時間目には体温 $6 \sim 9{ }^{\circ} \mathrm{C}$ 低下し注射後 4 時間目頃 が極期である。注射後 2 時間目に高温に曝露すると解放 の直後には平温近く字で上昇し，1.5時間目には再じ曝 露直前の低体温に逆戻りする。高温に曝露した 2 匹のう ち 1 匹は曝露解放後56時間目に死亡した。 
第 8 図 Chlorpromazineによる実験
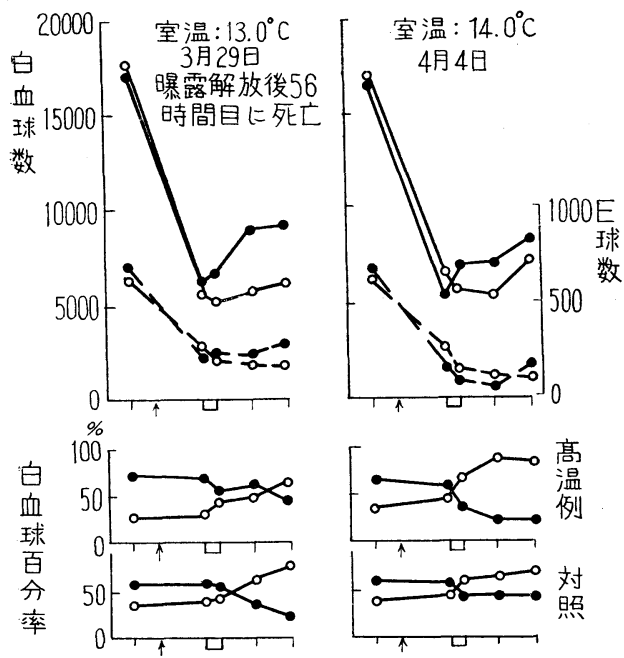

$\uparrow \quad$ 洼射 40 分の高温曝露 $\}$ を意味する。 $\{\mathrm{O}-\mathrm{O}$ 高温曝露例の白血球 \{-8 対照の 泉血球 白血球百分率では

○一○ 好中球

-一淋巴球

第9図 Chlorpromazine による体温の変動
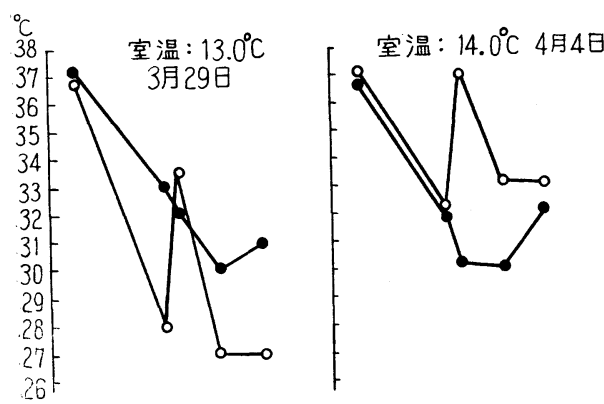

暴露解放後 56 時間目に死亡
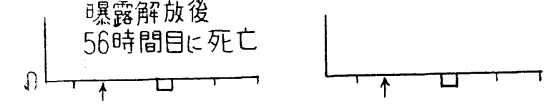

$\uparrow \quad$ 注射 ○一○高温飞曝露した白㸚ずみの体温 - - 対照 の体温

\section{考察}

第 2 報2) で報告したように, $\mathrm{P}^{32}$ 皮下注射後 $40^{\circ} \mathrm{C}$ に 30 分間曝露すると単純に高温に曝露した場合とは異なり,
解放の直後に白血球数が定型的に減少する場合はごくわ ずかで, 多くは減少しないか反対汇増加する傾向さえ現 わ礼る。すなわ占 $\mathrm{P}^{32}$ 注射活 stress の症候としての高 温曝露後の白血球数減少々乞㣗続く増加という定型性 をくずしてし宗う。そこで本実験では $\mathrm{P}^{32}$ 以外の白血球 数索増減させる薬剤 6 種を選び, これらでの前処置が高 温曝露後の白血球数变動の定型性にどんな影響をむつか を検討したのである。そして得られた結果は上述のよう に4つの型に分汀られた。

白血球数の神経性調節中枢が視床下部に亦ることは古 くよりいわれているが3〉-8)，增減と自律神経系との関係 については, 例えば增加の場合は副交感神経系緊張によ るとする説 ${ }^{23)}$, 反対に交感神経系緊張仙よるというまつ たく相反した説が唱えられている25現状で，い:なお不 明の点が多い。

$\mathrm{P}^{32}$ 亿よる白血球数増加作用は $\mathrm{P}$ 骨, 殊汇骨䯣球 ${ }^{26)}$ への親和性と $\mathrm{P}^{32}$ の放射性の特異性 ( $\beta$ 線エネルギーの 強いとと）とが骨䯣の造血作用学直接的に刺㦸するため ではないかと考えられる。勿論とのょうな $\mathrm{P}^{32}$ 亿ょる白 血球数増加は一般的䚺放射線照射の場合に起る initial leucocytosis であるかもしれず，実験的根拠がないので いずれとも決めがたい。しかし Adrenaline, Whooping cough vaccine, Diiodtyrosine, Mercazole, Chlorpromazine 抬よび ACTH のいずれが゙前処置して高温任 曝露すると白血球数の変動は上記のような 4 つの型に分 けられ， $\mathrm{P}^{32} て ゙$ 前処置した場合は次汇述べるWhooping cough vaccine 処置の場合とまつたく同様价る。すな わち高温曝露による白血球数の变動と $\mathrm{P}^{32} 32$ 注射による それとが単純倕重り合つたような像交し， $\mathrm{P}^{32}$ を注射 しただけで高温に曝露しなかつた動物（第 2 図の対照動 物)では stress 反応としてのショック期の白血球数減少 がみら扎ない。したがつて $\mathrm{P}^{32}$ による白血球数増加之高

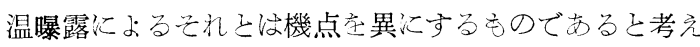
られ, 上記の推定のように $\mathrm{P}^{32}$ 亿よる白血球数増加仗 stress の一症候ではなく, 造血作用への $\mathrm{P}^{32}$ の直達作用之 するのが合理的のよ う纪思える。渡边らが $\mathrm{Sr}^{89}$ 户 $\mathrm{Ce}^{144}$ によるょりは $\mathrm{P}^{32}$ 亿よる実験的白血球病の発生率が高 いとしている24)こともとのような $\mathrm{P}^{32}$ の骨䯣汇対する直 接的作用と関係する事実ではなからうか。このような推 論からは高温曝露の白血球数増加作用は $\mathrm{P}^{32}$ の白血球数 増加作用とは機点を異にすると考えられる。したがつて 高温眿露後の白血球数増加は末梢性ではなくて中枢性つ ものではないかと考えられる。

stress 漈して警告反応期の初めのショック期 (shock 
phase）に扟こる一過性の淋巴球減少は Selye によれば lymphocytolysis であり，沖中らもこれを支持してい

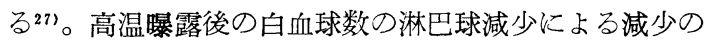
あとの増多は好中球增加によるととは前報にも示したと 扣りである。との好中球增加の stress との関連につい ては Selye は抗ショック期 (counter-shock phase) の 現象としているだけで, その増加機点についてはわれわ れの知る限りでは見解をのべていない。Whooping cough vaccine で処置すると白血球数は増加し, 約 5 時間 で最大となり処置前の $2 \sim 3$ 倍汇達する。との時期に高 温に懪露する之単純曝露時と同様の淋巴球减少とそれに 続く好中球増加が起る。ところで Whooping cough vac cine の白血球数増加作用は井上によれば vaccine の造 血藏器への直接作用, すなわち末梢性だとしている28)。 したがつて $\mathrm{P}^{32}$ 前処置も Whooping cough vaccine 前 処置もともに末梢性の白血球数增加を起すものと考えら れ, ただ $\mathrm{P}^{32}$ 前処置の場合は白血球数増加の続いている 時期に加温したから減少が消え, vaccine 前処置の場合 は増加の極期に加温したから減少が現われたと解され る。また $\mathrm{P}^{32}$ 前処置の場合の高温曝露尤る白血球数増 加 (好中球増加) が単純な滈温曝露の場合より強い傾向 のあるもの $\mathrm{P}^{32}$ 亿よる増加と加温による増加とが重り合 つたものと解される。との成績も高温曝露による好中球 増加は $\mathrm{P}^{32}$ やWhooping cough vaccine による増加の ような末梢性増加ではなくて, 中枢性のものだという考 えに合致する。井上も白ネズミを $55 \sim 60^{\circ} \mathrm{C}$ 亿 10 分間曝露 した時の白血球数増加は中枢性のものだとしている28)。 ただしこれは stress 学説の現われない頃の知見である から勿論 stress との関連などは問題になつていない。

Chlorpromazine で処置して白血球数減少の極期に 高温に曝露すると白血球数は減少も増加もしない。高温 から解放直後の減少は上記のように lymphocytolysis, すなわち stressに際して分泌される副腎皮質ホルモン (glucoproteid か mineralcorticoid かは Selye も触れて いない）による淋巴組織破壊によると解されている。し たがつて Chlorpromazine で前処置すると高温懪露後の 淋巴球減少が起らないのは Chlorpromazine の自律神経 系遮断作用によつて直接的にか宗たは間接的代 Stress が発現しないからであろう。その機作についてはいろい ろな議論があるが植村によれば Chlorpromazine は下 垂体上位ないし以前で自律神経系を遮断し, その結果下 垂体機能が 抑制されて ${ }^{22)}$ stress が発現しないという。 stress が現われない以上高温曝露後の白血球数減少が起 らないのは当然であるし，またその後に続くべき白血球
数增加も，上記の推論のようにそれが中枢性のものとす るなら消失するのは当然であろう。

高温曝露による白血球数変化についてとのような推論 は Adrenaline 処置の場合さらにはつきりする。との場 合は白血球数増加の極期汇高温比露したのであるが, 上述の Whooping cough vaccine または $\mathrm{P}^{32}$ 処置の場 合と同じょうに, 曝露直後には白血球数虫直前值より減 少しついで増加し, Adrenaline 処置にょる白血球数増 加と高温曝露によるそれとが単に重り合うにすぎな。 Adrenaline Kよる白血球数増加が末梢性の増加である ととは一般に認められている281。したがつて Adrenalineで前処置して高温曝露した場合の白血球数増加は末 梢性の増加に 高温曝露による増加が 加わつたと考えら れ, 高温曝露そのものによる白血球数増加は末梢性では なく中枢性と考えるのが合理的である。またAdrenaline の交感神経緊張作用から考光皇高温曝露後の白血球数 増加は交感神経緊張性のものではないかと思われる。本 実験では Adrenaline 注射後白血球数増加の極期に高温 に曝露してをり, 被験動物の曝露後の白血球数増加の時 期, すなわち曝露後 1.5 時間目は対照動物ではなお極期 から 2 時間目である。との時期には Adrenalineによる 白血球数增加は増加から減少沙つてはいるが, Adrenaline 注射前の正常值より梳明られ増加しているか ら, 交感神経緊張の存在は断言できないまでも克分期待 できる。もし高温嚗露後の白血球数增加は, それが副交 感神経緊張性のものとするなら, Adrenaline 前処置で 当然影響されるに違いない。しかし実験成績は明ら汃 Adrenaline が高温曝露による 白血球数変化の 定型性化 影響しないことを示しているから交感神経緊張性のもの と考えるのが罗当であるう。

$\mathrm{ACTH}$ 前処置後に高温に 曝露すると白血球数は開放 直後にははつきり減少するが, それに続く増加は非常に 弱い。とのような成績は次のよらに理解される。すなわ 5 ACTH 前処置は stress 学説からいつて当然 storessor を生体に加えることなく生体内にstress 起すから, 高 温が storessor として加わつてもショックとしての lymphocytolysis は一応起るがその後の抗ショック期の好中 球增加は軽減されたのだと考えられる。とのととは抗シ ヨック期の白血球数増加は高温暴露によるショックから の回復作用の必要度または回復作用の強度を表示するむ のではないかという考えをさそう。つ宗り ACTH 処置 によつて高温曝露によるショックを消失させることはて きないけれど，あらかじめstress体勢をとるととによつ て正常状態への回復が末処置より容易になつたのであろ 
う。とのととは ACTH の効力判定に Cold test，すな わち ACTH による耐寒性の増加が利用される391ととか ら考えても当然考えれらる。

Diiodtyrosine 前処置法高温曝露後の白血球数変化化 対しては添ぼ ACTH 処置の場合と同様の影響を示し， 白血球数柱高温曝露より解放直後は減少はするがその後 の増加は著明ではない。とのととは Diiodtyrosine が高 温曝露に際して ACTH と同じょうと有利に作用したの ではないかと考元らてる。 Diiodtyrosine については

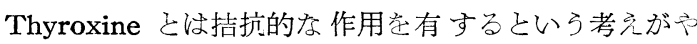
や強いようであるが，そうでないという人もある291。奖 た暒原らは Diiodtyrosine は夏季にはかえつて甲状腺機

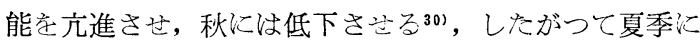
高温暴露に対しては不利だが秋に括ける曝露の場合には 有利だとしている。本研究て抬ける Diiodtyrosine 前処 置実験は 4 月下旬に抬こなつたもので, 暒原らは春季に ついては触れてないが，上記のように Diiodtyrosine 前

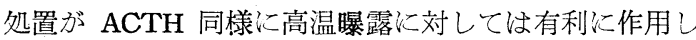
たと考えられ，乙机は Diiodtyrosine が春季心は甲状腺 機能を低下さやるためではないかと思われる。ともかく も $40^{\circ} \mathrm{C}, 30$ 分曝露解放後の白血球数増加は Diiodtyrosine の甲状腺機能低下作用によつて軽くてすんだこ考 えたい。

第 2 報2,で追究したように橉代謝関しては高温！露 後の回復期, すなわ $540^{\circ} \mathrm{C}, 30$ 分曝露後 3 時間目に注心

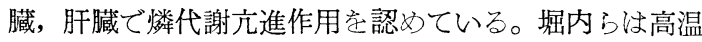
曝露時の臟器組織の $\mathrm{P}^{32}$ 摂取は減少し, 臓器中の $\mathrm{P}^{32}$ 保 留は高温曝露付対して有利に作用するとしている311。し のような成績からみても肝臓, 心臓の燐代謝機能六進は 高温曝露による体内代謝異常からの回復の現象であるこ とは確かであろう。

しかしその本質については想像にすぎないが次のょう な諸過程が考えられる。心臓の燐代謝充進は高温曝露に よる循環機能元進によつて生じた心筋の疲労加の回 復, すなわち A T P 合成の促進定意味する己考えられる が, 肝臓の燐代謝機能立進については高温㩧露の肝機能 に対する知見が買弱なので具体的代謝過程をあげること は現在ではまだむずかしい。しかし stress に際して肝臟 の Glutathione の念激な動摇は榊原 ${ }^{42}$ 打よび渡辺らの 報告(4) からも想像され，また ACTH 投与が血液 Glutathione 安一過性減少させるととも知引れている44)。 さらになた最近，肝蔵のミトコンドリアには水やある種 の電解質を蓄積したり分泌したりする機能が存し，これ がミトコンドリアの oxidative phosphorylation と関連
するととが明らかになつている45)。したがつてそのよう なエネルギーを要する調整過程にも肝臟の Phosphorylation の六進は役立つことも考えられる。Glutathione 合成がそのエネルギーをＡＴＰ方ら受けるととは Bloch

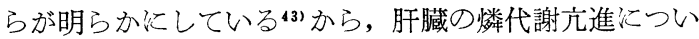
てもやはりその一過程としてA T P の合成の促進堂考元 るととはできるだろう。

このような肝臓扔よび心臓の燐代謝充進という知見は 高温曝露後のこの時期の生体が正常への回復の促進に対 して, 自律神経系機能使いて副交感神経緊張上り恔 感神経緊張状態をもつて対すると考える万がより合理的 であろう。とのような見解は黒津ら ${ }^{40}$ が交感帯刺战によ り酸性执よびアルカリ性 phosphatase が肝臟と十二指腸 で増加するとし，かつ白血球数す増加するとしているの とは非常代よつじつ导が合う。このょうな考察からは 高温曝露解放後の淋巴球減少のあとに起る好中球増加は 中枢性であり，かつ交感神経緊張性のもので，高温曝露 亿よる代謝立進の結果生じた諸異常から正常への回復過 程に随伴するという推論代傾かざるをえない。そのよう な異常の具体的知見についてはわれわ礼の知識注現在な 抢賀弱なものであるが, 酸素消費量の増大 ${ }^{37}$, 血清沃度 酸值の上昇 ${ }^{36}$, 尿中 $\mathrm{C} / \mathrm{N}$ 值の ${ }^{38}$ 増加, 尿酸排泄減少, ${ }^{41}$, 血中水分扮よび無機質の量的変動 ${ }^{31}$ 血夜 $\mathrm{pH} の$ 変動, ビタミン $\mathrm{B}_{1}$ と C (殊に還元型) の減少などの知見はこ れ良するむのであるう。

Mercazole で前処置すると白血球数以減少するが，こ 机は Mercazole の自律神経系性臟器の酸素消費抑制作 用から及て恐らく末梢性の造血作用低下によるもので文 ろう。Mercazole で前処置した白ネズミ以解放後の減少 も气れに続く増加も明膫ではないがその傾向は看取され る。曝露中のネズミは他覚的汇発汗様現象（ネズミでは 唾液定体表涂りつける) が末処置動物より軽度で, か $\supset$ Chlorpromazine 前処置の場合の上5に高温曝露によ る死亡というょうなとともなく，明らかに Mercazole 前 処置は高温䀧露江対しては有利汇作用したと考元られ る。これは, Chlorpromazine の上らと自律神経系定遮 断することなく，代謝在低下させたととによるのである 引。

生体が高温化さされた時汇交感神経緊張化傾くか, 副交感神経㗨張仙傾くかはいまな掞議論の 余地がある が32235)，一般には三浦が指摘しているように高温懪露は 生体を副交感神経緊張に傾かやるという考えが強いよう である10)。ただしそれが高温汇対する順応か高温の生体 えの作用の結果加三浦も疑問をのとしている46)。また 
長期間化わたつて高温が 生体へ作用する場合は生体の 順応俻視点が向けられている。例えば夏季の高温と冬 季の低温が生体にどのような差異をもたらすかという点 では生体の季節的順応が問題となつているょうである。 原島らは夏季は交感神経緊張傾くとしているが, 副 交感神経緊張, ときには好中球百分率減少し, 反対に交 感神経緊張のとき憎加するとしている321。しかし本実 験のょうな一過性の高温曝露では酸素消費増大, 脈搏 增加なぞからも直ち汇想像されるょうに生物学的常識㣻

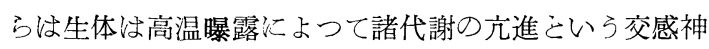
経緊張時江類似した影響を受汀るから, 生体注その homeostasis 維持のために全力当げて副交感神経緊張性 に向かうのが当然上想像される。例六ば曝露中の白ネズ ミの発汗現象络汗線がないので口と前肢の届く限り唾液 を塗りつるととによるもので，空るで汗びつしょりの姿 を呈し, 筆者らも初めは普通の発汗とさえ間違えたくら いである。本来発汗現象怯解剖学的汇恔感神経促進的 であるが, 蒋学的飞は副交感神経緊張性子解されて抢り 33) 34)，とのようなネズミの陲液分泌汇上る㲘命な放熱の ための努力は生体内での高温曝露の直接的響影仗るる諸 代謝立進抑制のための副交感神経緊張を思わせる。そし

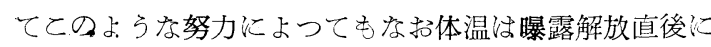

1.1〜 4. $0^{\circ} \mathrm{C}$ の昇が認められた。しかしChlorpromazine 処置ネズミは解放值後化は曝露前值より $6 \sim 9{ }^{\circ} \mathrm{C}$ ちの体温上昇があり，1匹は56時間目にはつい死亡し たの定及ると，自律神経的調節がなけ沉济 $40^{\circ} \mathrm{C}, 30$ 分曝 露江対してはネズミは物理的加温化近い状態江就れる のであろう。したがつてネズミは $40^{\circ} \mathrm{C}, 30$ 分の曝露対 して自律神経系化よつて $6 \sim 9{ }^{\circ} \mathrm{C}$ 上昇すべき体温変化を $4{ }^{\circ} \mathrm{C}$ 以下汇抑えているということができ，これ泮なう 諸変化の回復が扢てなわれる時期汇注交感神経系の緊張 状態汇あると考えられる。そしてュの一つの街候として 好中球増多による白血球数増加が末梢血化現われるもの と解したい。原島らが一般的仔中球增加は交感神経緊 張性だとしているのもとのような見解仙は有利な知見の 一つである。結局, 一過性の高温暴露化対してはネズミ は念ず副交感神経緊張的化対抗し, 対抗しきれず却起つ た異常に対しては交感神経緊張的な回復をもつてのでも という結論化達する。

前記のように Selye 淋巴球減少仙続く抗ショック期 (counter-shoch phase) の好中球增加には明確な意味 き与えてないが, 上記の考察が真化妥当なものか他の storessor 加えた場合，あるいは高温懪露を長くした 場合などの検討によつてょり明確にするととができょ
う。ともかくも加温沉よる白血球数増加は中枢性のもの であるととはかなり古くから報告されて抢り, 当時注 stress 学説がなかつたので stress の一徵候としての考 察はなされててないが, $40^{\circ} \mathrm{C}, 30$ 分懪露後のネズミの好 中球増加は中枢性のものであるととは本実験成績からも 志ず確実だといいたい。そして本実験成績からは高温曝 露後の好中球増加待, 淋巴球減少が间温暴露儿よるショ ックすなわち直接的影響の一症候であるの亿対して, シ ョックからの回復過程の活溌度の一症候であり, かつ高 温曝露では少く已も交感神経緊張性のものと考元る方が 副交感神経緊張性とするよりは合理的であることを知つ た。近時自律神経系緊張化重点を抢くReilly の説も stress 学説と己もに重視されるよ5になつている。本実 験結果の考察江当つて stress 学説のみで考えて矛盾とい う深どのものにはぶつからなかつたが, Selye の説は自 律神経系に対する配慮が久计ているととは上記の考察心 らも明らかである。な打成績の項でのべをようと対照動 物にはすべて注射後 $\mathrm{E}$ 球数の減少㧍よび好中球と淋巴球 百分率比の逆転が起り，白血球減少は及られなかつた が, これはやはり前処置としての注射行為々のむのが軽 い storessor になつたためであろう。動物に上つてはを 何を注射されょうとも注射処置そのもの対して精神的 飞は強い恐怖を感ずるであろうから，注射行為自体が storessor となりうるととは充分理解される。それにし ても Selye のいう Storessor は余りにも非特異的だとい う印象が深い。生体に対する刺战の特異性に対しては本 実験の場合でもやはり自律神経系的考虑が, 空つたく当 然のととながら, 必要であつた。

本実験注高温曝露時の恒温動物に打汀る生体変化の基 礎的知見を獲得するととを目的としたものであり，高温 曝露時の燐代謝を足がかりとして高温曝露による白血球 数増加にその一拠点を見出しえたものと考える。そして 恒温動物は季節的には夏季は副交感神経緊張に傾くこと は確からしいが, 本実験成績からは一過性の高温曝露に 対しては，季節を問わず，高温曝露中にはまず副交感神 経緊張的に対処し, 高温加解放後に注交感神経緊張的 に回復を抢てなうのだという見解学主張したい。

\section{結論}

第 1 報で報告したような, 白ネズミを高温 $\left(40^{\circ} \mathrm{C}\right)$ に 曝露 (30分) したのちに起る白血球数減少々それに続く 増加に対して，6種の薬剤のいずれかで前処置するてと がぞのような影響を及济すかを観察して次のね: 引な成績 を得た。

1)Adrenaline または Whooping cough vaccine 前処 
置活曝露による白血球数の減少とこれに続く增加の傾向 には影響しない。

2） ACTH 点たは Diiodtyrosine で前処置すると高 温䀧露後の白血球数減少注起るが, それ続く増加は著 明でない。

3） Mercazole で前処置すると曝露後の白血球数の減 少も増加き㑯向没認められるが著明でない。

4）Chlorpromazine で前処置すると曝露後の白血球 数の減少も增加も态つたく現われず，体温は上昇著しく

2 匹のう占 1 匹流 56 時間目に死亡した。

以上のような成績と第 2 報に打订る高温曝露の燐代謝 一の影響已走併世考元て, 一過性の高温淂露された白 ネズミのショックからの回復期の好中球増多による白血 球数増加は交感神経緊張性のものであるととを推定し た。さらに一般的にいつて白ネズミはとのような高温曝 露代対して曝露中淔副交感神経緊張的に対処し, 解放後 は交感神経緊張的江回復它営学考光うる可能性を見出 Lた。

終始御㦝篤な御指導と御校閲を賜わつた 西尾一男教 授扣よび本研究に対して便宜を与兄られた北原経太教 授に深謝する。

\section{文献}

1）宮本利哉：生化学, 28, 10, 623. (昭和31年).

2）宮本利哉：鹿児島県立大学放射性同位 元素研究 会報告，6 号, 10 (昭和32年).

3）亘・越智 : 大阪医学会雑誌， 27, 10 (昭和 3 年)

4) G. Rosenow : Zeitshrift f. d. ges. Exp. Medizin, 64, 1924.

5) F. Hoff u.v. Linhardt : Zeitshrift f. d. ges. Exp. Medizin, 63, 277. (1928).

6) W. Borehadt : Archiv f. Exp. Pathologie u. Pharmakologie, 137, 69, 1928.

7) 後藤 一：千葉医学会雑誌 .8 , 上・下（昭和 5 年).

8) 桜井之一：朝鮮医学会雑誌，23，1528 (昭和8年)

9) Joseph A. Tuta: Folica haematologica, 57, 122, 1937.

10）井上重利：熊本医学会雑誌，14，5，1285（昭和 13).

11) 井上重利：熊本医学会雑誌， 15，5，631（昭和 14 年).

12) 土肥 昂：京城医学専門学校紀要, 5, 1 (昭和 10年).

13) 原 勝巳 : 岡山医学会雑誌, 450 455, 下, 1914 (昭和 2 年).
14）林田満夫：熊本医学会雑誌，12，3 (昭和11年).

15）武藤・石䚾：京城医学専門学校紀要， 3, 6 (昭和 8 年).

16) H. Baar : Zeitshrift f. d. ges exp. Medizin, 50, 594 (1926).

17) A. Adler u. E. Blumberg., : Zeitshrift f. d. Klin. Med., 95, 109 (1922).

18) W. Frey u. S. Lury., : Zeitshrift f. d. ges. Medizin, 2, 50 (1914).

19) 三浦豊彥・他：労働科学，29，3，9(昭和25年).

20) 古藤憲二：慶応医学，28, 8, 393 (昭和26年).

21) Geoge W. Thorn: J. A. M. A., 137, 1005. (1948).

22）植草 実：日仏医学，2，2，125 (昭和32年).

23）井上重利：血液学討議会報告，第 3 輯，73（昭和 25年) 永井書店.

24）渡辺 漸：日本病理学会会誌，46, 3, 215（昭 和32年)。

25) 勝沼精蔵：日本内科学会雑誌，23，1，25（昭和： 10年).

26）太田和雄・他：医学シンポジウム第 12 輯, 放射 性アイソトープ，診断と治療社，401 頁（昭和31 年).

27）冲中重雄・他：血液学討議会報告，第 6 輯，129: 頁 (1954) 永井書店.

28）井上重利：血液学討議会報告，第 3 輯，66頁 $(19$ 50) 永井書店.

29）冲中重雄：自律神経飞臨床，67 頁（昭和30年） 杏林書院.

30）崎山敏雄 : 大阪医学会雑誌, 36, 457 (昭和 12 年).

31）大和田国雄 - 他 : 大阪市立大学医学雑誌，5，6, 720 (昭和 31 年).

32) 原島 進 : 環境衛生学, 339頁 (昭和29年) 南江堂

33）大崎隆三 : 生化学, 29, 10, 786 (昭和33年)

34）冲中重雄：自律神経系飞臨床，38頁（昭和30年） 杏林書院.

35) 菊野正隆：医学々生物学，16,110 (昭和 25 年).

36) 奥野博司: 生化学, $27,10,661$ (昭和31年).

37）鈴木武夫 - 他 : 労働科学, 33, 243 (昭和 31 年).

38）高石新次：大阪医学会雑誌，35，8，1551（昭和 11年).

39）中尾健他：内分泌のつぞい第 7 集，188（昭和30, 年) 共同医書出版社.

40）有薗初夫：大阪大学医学雑誌, $2,3,23$ (昭和 25 年).

41) 藤岡 普：大阪大学医学雑誌, 2, 3, 17 (昭和 25 年).

42）久成正生：労働科学季報, 4, 1 4 合併号, 49 ， (昭和30年).

43) K. Bloch, J. E. Snoke \& S. Yanari, Phosphrus Metabolism, II, 82, Johns Hopkins University (1952). 


\section{[368]}

44) 永井敏彥・他 : 労働科学, 32, 5, 390（昭和 31 年).

mic Press Inc., Publishers (1956).

45) Albert L. Lehninger: Enzymes: Units of Biological Structre and Function, 217, Acade-

46) 三浦豊彥: 労働科学，27，2，5 (昭和26年)。

（受付： 1958 年 2 月 20 日，特別揭載） 